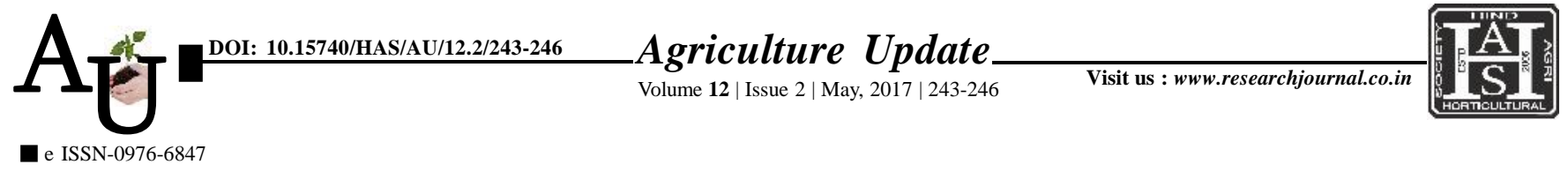

\title{
Research автіcle: Knowledge level of disadvantaged women beneficiaries on production technologies of horticultural crops in Tripura
}

D DIPAK NATH AND SUBHRA SHIL

Article Chronicle: Received :

27.02.2017;

Revised :

18.03.2017;

Accepted :

01.04.2017

KEY WoRds:

Women beneficiary,

Knowledge level,

Production

technology,

Horticultural crop

Author for correspondence :

\section{DIPAK NATH}

Divyodaya Krishi Vigyan Kendra, KHOWAI (WEST

TRIPURA) INDIA

Email:spd020@yahoo.

co.in

See end of the article for

authors' affiliations
SUMMARY : The study was conducted among the women beneficiaries of Divyodaya Krishi Vigyan Kendra, Tripura West district of Tripura. A total of 200 respondents belonging to SC and ST population were selected randomly from the 14 purposively selected villages. The study revealed that 49.00 per cent of the respondents had high level of knowledge followed by 37.50 per cent in medium and 13.50 per cent respondents in low level of knowledge category on production technologies of horticultural crops. The socio-personal characteristics like age $(\mathrm{r}=0.761)$, educational level $(\mathrm{r}=0.890)$, mass media exposure (0.767), family's operational land holding $(\mathrm{r}=0.649)$ and social participation $(\mathrm{r}=0.759)$ had positive and highly significant relation whereas marital status ( $\mathrm{r}=0.541)$ and family type $(\mathrm{r}=0.534)$ had positive and moderately significant relation with the knowledge level of women beneficiaries on production technologies of horticultural crops.

How to cite this article : Nath, Dipak and Shil, Subhra (2017). Knowledge level of disadvantaged women beneficiaries on production technologies of horticultural crops in Tripura. Agric. Update, 12(2): 243-246; DOI : 10.15740/HAS/AU/12.2/243-246. 